\title{
COMPENSATION FORMULAS FOR COURT AWARDED ATTORNEY FEES
}

\author{
Marshall J. Breger*
}

I

\section{INTRODUCTION}

More than 150 state and federal statutes ${ }^{1}$ allow courts to award attorney fees to parties substantially prevailing ${ }^{2}$ in litigation. Few of these statutes, however, specify what formula courts ought to use when making fee awards. ${ }^{3}$ At present, the question of how much losers must pay to winners is a matter of judicial construction of statutes which provide only that the fees awarded be "reasonable." ${ }_{4}$ The absence of standards has resulted in a lack of uniformity among trial court fee awards. In an effort to develop standards, courts began to require compensation at the "prevailing market rate." The Supreme Court has recently endorsed this approach. ${ }^{5}$

This article will first analyze different approaches to compensation rates in light of various theories of attorney fees. Second, it will review the case law developing the compensation formulas for court awarded fees and will consider the legislative history of statutory fee shifting. Finally, it will explore the meaning of the prevailing market rate formula and will show that courts using such a formula commonly misapply market rate analysis and fail to appreciate the need for a

Copyright $(\mathcal{C} 1984$ Law and Contemporary Problems

* Associate Professor of Law, New York Law School (on leave); Visiting Fellow in Legal Policy, The Heritage Foundation, Washington, D.C.

This essay was substantially completed prior to entering government service as Special Assistant to the President for Public Liaison. Nothing in this article should be construed as the position of the United States Government.

I wish to express my thanks to Stuart Rosenthal for his valuable research assistance and editorial advice.

1. A list of federal statutes is provided in an appendix to Ramos v. Lamm, 539 F. Supp. 730,755 (D. Colo. 1982). See also Attorney Fee Awards Reporter, which lists statutes in the index of each issue.

2. The term "prevailing party" has become a term of art. By judicial construction, fee awards have been limited for the most part to prevailing plaintiffs on the grounds that (a) plaintiffs have been chosen to implement this given congressional policy, and (b) an award to a prevailing plaintiff is generally paid by an opposing party who has violated federal law (not true of the converse situation of a prevailing defendant). See Christiansburg Garment Co. v. EEOC, 434 U.S. 413 (1978). Absent some success on the merits, a party is not entitled to a fee award. Ruckelshaus v. Sierra Club, 103 S. Ct. 3274, 3281 (1983). However, when a plaintiff prevails on some counts, he can recover fees for the work expended on successful claims. Hensley v. Eckerhart, 103 S. Ct. 1933, 1940 (1983).

3. See, e.g., Equal Access to Justice Act, 28 U.S.C. $\$ 2412$ (d)(2)(A) (1976) (establishing \$75-per-hour cap for attorney fee awards in suits against the United States absent court determination of special circumstances justifying higher fee); 38 U.S.C. $\$ 3404$ (c) (1976) (attorneys may not collect more than $\$ 10$ for representing a claimant before the Veterans' Administration); International Claims Settlement Act, 22 U.S.C. $\S 1623(\mathrm{f})$ (1982) (limits compensation to $10 \%$ of benefits paid to claimant).

4. See, e.g., Civil Rights Attorneys' Fees Award Act, 42 U.S.C. $\$ 1988$ (Supp. V 1981).

5. Blum v. Stenson, 104 S. Ct. 1541 (1984). 
determination of reasonableness. While encouragement of litigation through fee shifting is a policy articulated in present statutes, awards based on the conventional (yet, in the view of this author, erroneous) theory of "prevailing" market rates may well lead to excessive fees, thus creating incentives for excessive litigation.

\section{II}

\section{Justifications for Court Awarded Fees and Compensation FORMULAS}

Traditionally, both plaintiffs and defendants in American courts bear their own civil litigation costs. ${ }^{6}$ In contrast to this "American rule," the British legal system typically indemnifies the winning party, whether it be plaintiff or defendant. ${ }^{7}$ However, common law exceptions to the American rule have long permitted courts to award fees against a losing party that acted in bad faith. ${ }^{8}$ More recently, statutes have been promulgated which permit shifting fees onto defendants in order to encourage litigation or subsidize public law suits. ${ }^{9}$

It is important to distinguish among and analyze the major rationales for requiring one party in a dispute to pay the fees of another. In brief, there are four justifications: ${ }^{10}$ to make a prevailing party whole, to encourage certain types of litigation, to punish certain types of parties, and to provide financial assistance to the prevailing party or his attorneys.

\section{A. The Out-of-Pocket View}

In England and some other common law countries, attorney fees are awarded to ensure that prevailing parties-whether plaintiffs or defendants-are not out-ofpocket for vindicating just legal positions. ${ }^{11}$ Normally, the courts require losers to pay winners either "necessary and proper" or "reasonable" costs. ${ }^{12}$ In either case, the winning party must pay for nonessential services provided. In determining costs, courts take account of the client's expenses. Since awards never exceed fees billed, the central question is what a party was charged by his attorney. In many cases this is a routine matter. However, when a lawyer takes on a case pro bono, the

6. See Alyeska Pipeline Serv. Co. v. Wilderness Soc'y, 421 U.S. 240, 248 (1975).

7. See generally, Walker \& Walker, The English Legal System, ch. 20 (5th ed. 1980), and Goodhart, Costs, 38 YALE L.J. 849, 852 (1929).

8. See Alyeska Pipeline Serv. Co. v. Wilderness Soc'y, 421 U.S. at 258-9, and Newman v. Piggie Park Enter., Inc., 390 U.S. 400, 402 n.4 (1968).

9. See supra, note 1.

10. Rowe has made use of a somewhat different six-part classification of rationales which he sees as reflecting "three major strains equity, litigant incentives and externalities." Rowe, The Legal Theory of Allomey Fee Shifling: A Critical Overview, 1982 DUKE L.J. 651, 652-53.

11. See WALKER \& WALkER, supra note 7. See also Rowe, supra note 10, at 653-57 for arguments against such a "two-way" fee shifting rule.

12. Where the court awards costs "as between party and party," "[t]he taxing officer disallows any expenses not strictly necessary and proper to establish the party's case or defense." Where costs are taxed on a "common fund" basis, as is the case where a litigant's expenses are paid out of a legal aid fund, all reasonable expenses are recoverable. A. Kiralfy, The English Legal System, $271-72$ (5th ed. 1973). 
party represented has had no actual expenses. Strictly construed, the out-of-pocket rationale would prohibit compensation in such cases.

In the United States, public interest law firms or legal services programs that do not charge their clients would not be able to make a fee request under this rationale. On the other hand, if we were to adopt the view that many attorneys instigate public interest lawsuits on behalf of nominal clients, we could reimburse the cost of such representation even though the client was charged no fee. This raises the question of how to measure "actual cost" where no fee is set. As an employee of a legal aid program, a legal aid attorney is paid on the same basis as in-house counsel, that is, he receives a fixed salary. Thus, it could be argued, both in-house counsel and members of public interest law firms should be compensated for the hourly equivalent of their salary plus an allocation for overhead. With such a structure, counsel who take on a case gratis could be indemnified even utilizing the out-of-pocket view.

In short, when the market between attorneys and their clients cannot give us an actual cost figure, we may look to a substitute market, viz., that existing between attorneys and their employers, for assistance in determining a reasonable fee.

\section{B. The Encouragement Approach}

In contrast to the typical indemnification of winning parties typically resulting from the English rule, fee shifting under the American rule requires a judicial or statutory exception. ${ }^{13}$ Numerous federal and state statutes provide such exceptions, ${ }^{14}$ most often out of a desire to encourage specific types of litigation. The "encouragement" approach is premised on the view that particular types of litigation will not be brought without some form of subsidy (government or otherwise) to plaintiffs. ${ }^{15}$ This alleged "market failure" is corrected by statutes providing for court awarded fees designed to attract plaintiffs (or attorneys) to such litigation.

Generally, those who adopt this approach accept the sociological premise that many lawsuits are attorney-generated rather than client-generated, as well as the economic premise that attorneys will always seek income maximization. This perspective views an attorney's opportunity cost, that is, the money which he could have made had he taken a potentially lucrative case, as the minimum sum that will encourage him to take a less attractive case which we as a society might wish him to bring. ${ }^{16}$

13. See Alyeska Pipeline Serv. Co. v. Wilderness Soc'y, 421 U.S. 240, 260 (1975).

14. See supra, note 1.

15. If encouragement of certain types of lawsuits is for the public good, it is not clear why the subsidy should come from litigants rather than from the state. Rowe's suggestion that it would be "unfair, uneconomical and impractical" to externalize the costs of fee shifting recognizes this general concern but neatly avoids pursuing it. Rowe, supra note 10 , at 673 . One way to test whether the citizenry sees such litigation as a "public" good would be to offer Congress the choice between supporting it with public funds and taxing losers to pay winners.

16. It is sometimes assumed that the encouragement rationale does not apply to legal services and public interest law organizations. Some commentators argue that those legal services organizations which exist to provide counsel to the poor and are funded by state and federal governments choose their cases without reference to the likelihood of fee recovery. Indeed, there is a moral argument against paying fees 


\section{The Punishment Position}

Fees are sometimes shifted in order to punish misconduct either in the underlying transaction or in the course of the litigation. There are three justifications for this: to punish the offender, to provide additional compensation to the injured party, and to deter further improper use of the courts. ${ }^{17}$ As an example of punishment for transaction misconduct, under Georgia law a defendant is liable for the plaintiff's attorney fees if he breaches a contract in bad faith. ${ }^{18}$ Indeed, in many states, attorney fees are an element of punitive damages. ${ }^{19}$ The logic here is that such defendants are in some sense "bad" men who should be financially punished above and beyond compensatory damages. The power to levy such fees has been recognized as an inherent, equitable power of the federal courts. Thus, no statutory authority is required. ${ }^{20}$

The judicial decision to "punish" party-litigants or their attorneys can result from inappropriate conduct during the course of the litigation as well. These abuses include the bringing of meritless lawsuits and the use of harassing or delaying tactics. Recently, a federal district court ordered not the plaintiff but the plaintiff's attorney to reimburse expenses incurred in defending a meritless lawsuit. ${ }^{21}$ The judge relied on his "inherent" power under Rule 11 of the Federal Rules of Civil Procedure to tax an offending attorney with his opponent's legal fees. ${ }^{22}$ Also, 28 U.S.C. $§ 1927$ provides for assessment of fees against an attorney who "unreasonably and vexatiously" multiplies the proceedings. In the same vein, courts also have the power to award fees to a party who suffers from his opponent's

to state subsidized non-profit legal services providers: Financial considerations are inappropriate when selecting legal aid cases. The job of legal aid is to provide legal assistance to those who cannot afford to hire a lawyer without regard to the likelihood of recovering a fee. It should be noted that the Legal Services Corporation Act generally prohibits legal aid lawyers from accepting cases which generate fees. See 42 U.S.C. $\$ 2996 f(b)$ (1982).

On the other hand, others have argued that since government support and operating revenues are limited, even legal services organizations "would naturally be constrained to devote their energies to the kinds of suits in which fee awards are available." San Filippo v. Secretary of Health and Human Servs., 564 F. Supp. 173, $176-77$ (E.D.N.Y. 1983). See also Shadis v. Beal, 520 F. Supp. 858, 864 (E.D. Pa. 1981) ('In 'rationing' its resources [the state-funded legal services organization] must take into account the likelihood of obtaining attorneys' fees."); Breger, Legal Aid for the Poor: A Conceptual Analysis, 60 N.C.L. REv. 282, 313-328 (1982).

Indeed, many non-profit law firms are aggressively going after attorney fees to meet budget shortfalls. For example, the Center for Law in the Public Interest, a Los Angeles-based public interest law firm, received over 1.7 million dollars in fees in the period 1975-1980, more than half its budget. As a result, the firm had to seek a special exemption from IRS regulations governing qualifications for tax-exempt status. Too Much Cash Brings Woe to Law Center, Nat'l L.J., Feb. 4, 1980, at 3, col. 1.

17. See generally Maller, Punitive Attorneys' Fees for Abuses of the Judicial System, 61 N.C.L. REV. 613 (1983).

18. Ga. Code Ann. $\S 20-1404$ (1977)

19. See Annot., 30 A.L.R.3d 1443 (1970).

20. See Roadway Express, Inc. v. Piper, 447 U.S. 752, 765 (1980); Alyeska Pipeline Serv. Co. v. Wilderness Soc'y, 421 U.S. 240, 259 (1975).

21. See N.Y. Times, Feb. 9, 1984, at B9, col. 3 (discussing suit against Victim Services Agency of New York City).

22. On shifting fees under Rule 11, compare Driscoll v. Oppenheimer, 500 F. Supp. 174, 175 (N.D. Ill. 1980) (federal courts have inherent power under Rule 11 to grant attorney fees as a sanction), with United States v. Standard Oil of Cal., 603 F.2d 100, 103, n.2 (9th Cir. 1979) (Rule 11 provides no authority for awarding attorney fees against unsuccessful litigant) 
contempt of court, ${ }^{23}$ and to one who has been subjected to litigation with a third party due to another's wrongdoing. ${ }^{24}$

\section{The Financial Need of the Recipient Party or His Attorney}

Lurking in the background of much fee shifting discussion is the notion that public interest law firms and legal aid organizations are worthy of largesse. Following this view, one could award non-profit institutions exceptionally high fees on the grounds that they serve a useful social function and need additional funds to balance their budget. ${ }^{25}$ This position may well provide an underlying rationale for large fee awards often justified on other grounds. However well-intentioned, this position does violence to any general theory of attorney fees. The moral worth or desert of plaintiff's attorneys ought not have any relevance to the fee structure a court applies. It would not be fair to require defendants to support financially a plaintiff's decision to hire "good guys" as counsel.

\section{III}

\section{Fee Computation Case Law}

The standard cases regarding fee computation are the two Third Circuit opinions in Lindy Bros. Builders of Philadelphia v. American Radiator $\mathcal{E}^{\circ}$ Standard Sanitory Corp. ${ }^{26}$ and the Fifth Circuit opinion in Johnson v. Georgia Highway Express. ${ }^{27}$

The Lindy Court first developed some basic standards for fee awards. It began by multiplying the attorney's normal billing rate by the number of hours spent on the litigation. This calculation yielded a "lodestar" fee figure, deemed "the only reasonably objective basis for valuing an attorney's services." 28 This figure was then adjusted with reference to several criteria including the likelihood of success and the quality of the attorney's work. ${ }^{29}$

The Johnson Court borrowed a "laundry list" of criteria from the Model Code of Professional Responsibility for evaluating ${ }^{30}$ on which judges were to base their fee awards. The Jonhson list incorporated the lodestar elements and elaborated additional evaluative criteria:

23. See Roadway Express, Inc. v. Piper, 447 U.S. 752 (1980).

24. See Comment, Recovery of Attomey Fees from Third Party Tortfeasors, 66 Calif. L. REv. 94 (1978).

25. See Copeland v. Marshall, 641 F.2d 880, 899 (D.C. Cir. 1980) (Copeland III) ("Full fee awards to public interest law firms help finance their work, both in the instant case, and in others. Indeed, fee awards . may help reduce the subsidies . . that some of these organizations receive.").

26. 487 F.2d 161 (3d Cir. 1973) (Lindy N); 540 F.2d 102 (3d Cir. 1976) (Lindy II). The D.C. Circuit followed Lindy in National Treasury Employees Union v. Nixon, 521 F.2d 317, 322 (D.C. Cir. 1975); see also Groves v. Barnes, 700 F.2d 220, 222 (5th Cir. 1983); Furtado v. Bishop, 635 F.2d 915, 920-21 (1st Cir. 1980); Grunin v. International House of Pancakes, 513 F.2d 114, 127-28 (8th Cir.), cert. denied, 423 U.S. 864 (1975).

27. 488 F.2d 714 (5th Cir. 1974). The Johnson factors were applied in a bankruptcy context in In re First Colonial Corp. of Am., 544 F.2d 1291 (5th Cir.), cert. denied, 431 U.S. 904 (1977).

28. Lindy $I, 487 \mathrm{~F}, 2 \mathrm{~d}$ at 167 . The use of the lodestar approach and Johnson factors in each of the twelve federal circuits is annotated in 39 REC. A.B. CITY N.Y. 312 (May-June 1984).

29. Lindy $l, 487$ F.2d at $168-69$.

30. See Johnson, 488 F.2d at 717-19. This list is an elaboration of the Model Code's criteria for judging the reasonableness of attorney fees generally. MOdel Code of Professional ResponsibiLity DR 2106(B) (1980). 
- the time and labor required;

-the novelty and difficulty of the questions;

- the skill requisite to perform the legal service properly;

- the preclusion of other employment by the attorney due to acceptance of the case;

- the customary fee for similar work;

- whether the fee is fixed or contingent;

- time limitations imposed by the client or the circumstances;

- the amount involved and the results obtained;

- the experience, reputation, and ability of the attorneys;

-the "undesirability" of the case;

- the nature and length of the professional relationship with the client;

- awards in similar cases. ${ }^{31}$

In a trilogy of opinions, the Copeland $v$. Marshall case produced arguments both critical and supportive of the lodestar formula. ${ }^{32}$ Copeland concerned a fee award to Wilmer, Cutler \& Pickering, a Washington law firm, for representing Department of Labor employees in a Title VII sex discrimination case. In a settlement agreement, the plaintiffs received $\$ 33,000$ in back pay. Plaintiffs then requested payment of their fee "at the law firm's customary hourly rate," amounting to $\$ 206,000 .^{33}$ The district court discounted that request by approximately twentytwo percent, awarding the firm $\$ 160,000 .^{34}$ On appeal, a panel of the D.C. Circuit, suggesting the need for stricter fee shifting standards when the United States is a defendant, remanded the case, providing principles for an alternative fee award calculation. ${ }^{35}$ Thereafter, the panel denied rehearing, but issued a second, clarifying opinion. ${ }^{36}$ Ultimately, the appellate court reinstated the lodestar, market-based approach in an en banc opinion affirming the district court's original fee award. ${ }^{37}$

In Copeland I, Judge Wilkey rejected the lodestar calculation for a novel approach - a cost-plus-profit formula — which enjoyed a brief tenure until vacated by Copeland III. The cost-plus-profit approach separates the attorney's fee into three components: the proportionate salary paid the attorney, the allocable over-

31. It was suggested in Copeland $I I I, 641$ F.2d at 890 , that "District court judges . . . have had difficulty applying the Johnson factors. A common, yet understandable fault is for the trial judge to make the conclusory statement, 'after considering each of the twelve factors in Johnson, I find that a reasonable fee is $X$ dollars.' " Id.

32. See Copeland v. Marshall, 594 F.2d 244 (D.C. Cir. 1978) (Copeland I) (appellate court reversed district court fee awards and remanded for reconsideration under "novel" standards); Copeland v. Marshall, 20 Fair Empl. Prac. Cas. (BNA) 79 (D.C. Cir. 1979) (Copeland II) (motion for rehearing denied, but Copeland I clarified); Copeland III, 641 F.2d at 880 (en banc rehearing where Copeland I standards vacated and Lindy approach adopted).

33. Copeland III, 641 F.2d at 887.

34. Id.

35. Copeland I, 594 F.2d at 244.

36. Copeland II, 20 Fair Empl. Prac. Cas. (BNA) at 79.

37. Copeland III, 641 F.2d at 880 . The court also noted that in cases in which the firm had received a court awarded fee in public interest litigation it had traditionally contributed the fee to a public interest law firm. Id. at 883 n. 1 . 
head costs (including secretarial and paralegal services), and a return of profit to the firm. ${ }^{38}$ Such an analysis is more sophisticated than the lodestar approach because it requires a court to evaluate the various elements of a fee, rather than merely to accept a reported billing rate. In contrast to the simple lodestar approach, the cost-plus-profit standard specifically subjects to scrutiny both the salary paid each attorney and the overhead and profit margin allowed the firm before adjustments are made for the complexity of the case, the competence of the attorneys, the degree of success achieved, etc. In both the lodestar and cost-plus formulas, courts are called upon to apply the Johnson factors. ${ }^{39}$ The difference is in the determination of the "starting point." Judge Wilkey characterized his innovation as one abandoning the traditional hourly-fee lodestar "in favor of a principle of reimbursement to a firm for its costs, plus a reasonable and controllable margin for profit."40

Copeland III rejected this approach for several reasons. First, the court observed that the test posed considerable administrative difficulties. ${ }^{41}$ The problems associated with allocation of overhead costs, calculation of costs associated with "imputed salaries" for firm partners, and determination of a "reasonable" profit were deemed to raise "the specter of a monumental inquiry on an issue wholly ancillary to the substance of the lawsuit."42 Second, the court asserted that focusing on incurred costs rather than on market-based charges, was "fundamentally inconsistent" with the congressional purpose behind statutory fee shifting. ${ }^{43}$ Finally, the court noted that the earlier panel opinions gave no reasons why rates established by market pressures would in fact differ from those achieved through the cost-plus-profit computation. ${ }^{44}$

However, in New York Association for Retarded Children v. Carey, decided last year, the Second Circuit found that a cost-plus analysis would indeed yield rates different from a market analysis where non-profit attorneys are concerned. ${ }^{45}$ In Carey, the court was addressing the appropriate fee award standard for non-profit attorneys under the Civil Rights Attorneys' Fees Award Act of 1976. ${ }^{46}$ The legislative history of that Act did not clearly indicate how the drafters would figure fee awards. It simply called upon courts to award fees "adequate to attract competent counsel, but which do not produce windfalls to attorneys." 47

38. Copeland I, 594 F.2d at 251-52.

39. See id. at 244.

40. Id. at 251 (emphasis added)

41. Copeland III, 641 F.2d at 896-97.

42. Id. at 896 .

43. Id. at 897. The court stated that the legislative history of the Civil Rights Attorneys' Fee Awards Act of 1976, 42 U.S.C. $\S 1988$ (1976), made clear that a market rate was to be used. Id.

44. Id. at 898. See National Ass'n of Concerned Veterans v. Secretary of Defense, 675 F.2d 1319 (D.C. Cir. 1982) for a detailed elaboration of documentation requirements imposed on fee applicants recovering under the Copeland III approach.

45. 711 F.2d 1136 (2d Cir. 1983); see also Rahmey v. Blum, 95 A.D.2d 294, 466 N.Y.S.2d 350 (1983), where the court used a marginal cost analysis very similar to that in Carey.

46. 42 U.S.C. $§ 1988$ (Supp. V 1981).

47. S. Rep. No. 94-1011, 94th Cong. 2d Sess. 6 (1976). See also H.R. Rep. No. 94-1558, 94th Cong. 2d Sess. 9 (1976); Comment, Calculation of a Reasonable Award of Altomey's Fees Under the Attomeys' Fees Award Act of 1976, 13 J. MAR. L. REv. 331 (1980). 
The court, referring favorably to Judge Wilkey's cost-plus approach, found that an award of fees "to nonprofit lawyers based upon billing rates charged by profit-making lawyers inevitably produces a windfall." 48 This is because the salary and overhead components of a private firm's billing rate generally reflect greater expenses than those incurred by non-profit organizations and because the very notion of a "profit" component for a non-profit firm raises questions of reasonableness. ${ }^{49}$ While the court noted that a cost-plus formula would eliminate any windfall aspect of a fee, it declined to require such an approach in light of administrative difficulties and judicial precedents which frowned upon disparate treatment of profit-making and non-profit attorneys. Instead, the court permitted payment to non-profit attorneys based on the rates charged by comparably skilled attorneys in private practice-with one caveat: The court called upon district judges to familiarize themselves with the customary billing rates in their communities so that they could set a "break point" hourly-rate figure which would represent a fee for non-profit organizations short of a windfall. ${ }^{50}$ Beyond this figure, fees would be deemed to incorporate the higher overhead costs and profit component associated with profit-making firms.

The most recent and authoritative opinion on the subject of fee computation is the Supreme Court's decision in Blum v. Stenson, decided only last March. ${ }^{51}$ There, the Court found the language of the Civil Rights Attorneys' Fees Award Act and its statutory history to require calculation of reasonable fees "according to the prevailing market rates in the relevant community."52 The Court rejected arguments that market rates provide excessive fees to non-profit legal services organizations and that a cost-based standard should therefore be applied to their fee requests.

The Court focused on the three district court cases which were cited in the legislative history of the Act as applying correct fee shifting standards. ${ }^{53}$ Since the fee awards in those cases were based on customary billing rates, the Court drew the conclusion that Congress approved of the prevailing market rate approach. The Court did not take special note of Congress's further statement that "[ $t]$ hese cases have resulted in fees which are adequate to attract competent counsel, but which do not produce windfalls to attorneys. "54 The Court did not read this statement to require courts to scrutinize billing rates for windfalls to particular attorneys. Instead, without analysis, it assumed that prevailing rates are reasonable, advising that "[t]he policy arguments advanced in favor of a cost-based standard should be addressed to Congress rather than to this Court." 55

48. Carey, 711 F.2d at 1150 (emphasis added).

49. Id.

50. Id. at 1151

51. Blum v. Stenson, 104 S. Ct. 1541 (1984).

52. Id. at 1547

53. The cases were Stanford Daily v. Zurcher, 64 F.R.D. 680 (N.D. Cal. 1974); Davis v. County of Los Angeles, 8 Empl. Prac. Dec. I 9444 (C.D. Cal. 1974); and Swann v. Charlotte-Mecklenberg Bd. of Educ., 66 F.R.D. 483 (W.D.N.C. 1975).

54. Blum v. Stenson, 104 S. Ct. at 1546 (citing S. Rep. No. 94-1011 (1970) (emphasis added)).

55. Id. at 1547 . 
IV

\section{Compensation Formulas, Fee-Shifting Rationales, and the MARKET FOR ATTORNEYS}

The Supreme Court pointed out in Blum that the factors which affect fees in the market are too complex to replicate in the non-market fee shifting situation. ${ }^{56}$ Billing rates vary widely depending on the attorney's length of experience, ability, and status (i.e., whether he or she is an associate, partner, or "of counsel"). Not only is a partner's time worth more due to his greater experience and prestige, but the overhead attributable to him is likely to be far above that of an associate: Partners' larger, deluxe offices and additional support staff add to their overhead. Equally important, fees paid by a client are seldom billed at a flat rate. While firms may have a "public" billing rate for each attorney, the final bill is often adjusted, taking into account such things as the success of the representation, the quality of the work, the likelihood of future business from the client, and the ability of the client to pay. ${ }^{57}$

In lieu of going into all these factors in determining each fee request, a possibly Herculean task, the courts have taken two different approaches. The lodestar approach abstracts from all the complexity and variety in market-based attorney fees and instead adopts a general "bright-line" figure based on public billing rates. The cost-plus approach, in contrast, looks closely at the actual costs incurred by the particular provider of legal services. Both methods obscure what are potentially the most difficult problems of fee calculation, the former by ignoring particularities, the latter by focusing on them.

The two approaches also differ in their reflection of the four rationales for fee shifting discussed above. The cost-plus approach adopts a variant of the out-ofpocket view, making it possible to exclude "luxury" elements from the fee award. ${ }^{58}$ Rather than basing compensation on opportunity costs, fees can be based on expenses incurred plus a reasonable profit. Overhead costs geared to the needs and desires of corporate clients can be adjusted downward when pro bono work is undertaken. Similar downward revision can be taken with respect to attorney salaries and profit margins if the prestige of the firm and its typical clientele result in an inflated fee structure. This resembles the English view of fee shifting. A party whose expenses are to be paid by its adversary can recover all "necessary and proper" costs, but must be prepared to pay for non-essential services. ${ }^{59}$

The cost-plus formula also incorporates the encouragement rationale insofar as it deems compensation for costs plus a reasonable profit sufficient to encourage competent attorneys to take socially desired cases. Though such a fee would not equal the opportunity costs of the most highly paid corporate attorneys, it would not ultimately require any financial sacrifice on their part and hence should not discourage them from taking such cases pro bono publico. This is in keeping with

56. Id. at 1547 n.11. See further discussion infra notes $92-97$ and accompanying text.

57. See Copeland II, 20 FAIR EMPL. PraC. CAS. (BNA) at 82-83.

58. See supra pp. 250-51.

59. See supra note 12 and WALKER \& WALKER, supra note 7, at 364 . 
the encouragement rationale, the intent of which is to overcome the discouragement which results from unreasonably low fees.

In contrast, the "market rate" approach often promotes litigation through unreasonably high fees. Indeed, this approach, including the lodestar method, appears designed to subsidize public interest litigation and to punish "bad" defendants. It often will provide non-profit attorneys a greater award than will the cost-plus formula, especially when such billing rates are at the higher end of the market. ${ }^{60}$ Where the losing party is worthy of punishment or has a deep pocket, this may not be offensive. However, the higher award will have no logical connection to the appropriate degree of punishment ${ }^{61}$ and will, at best, have retributive and redistributive effects.

Though the punishment and financial need rationales could thus be argued to justify the lodestar approach, attorney fees have traditionally been used to punish misconduct only when there is statutory authority for punitive damages or when federal courts exercise their equitable power. There is nothing in the legislative history of the most often utilized fee shifting statutes to suggest that Congress saw all losing parties to be worthy of "punishment" through the awarding of exceptional fees. On the contrary, Congress has mandated that "reasonable fees" be awarded. ${ }^{62}$ We cannot assume that awards which indiscriminately reflect the billing rates of opposing counsel will in all cases be "reasonable."63 Should the purpose of this wealth-shifting be assistance to public interest attorneys, surely the preferable response is direct government subsidy through, for example, Legal Services Corporation grants. Requiring losers to pay going rates to all winners' attorneys not only puts the burden of subsidy on a relatively small sector of society, but subsidizes public interest and profit-making law firms alike.

If, then, both congressional intent and common sense favor an encouragement approach, in what ways can courts determine how much encouragement is needed to secure attorneys for lawsuits in the congressionally favored litigation categories?

Encouragement is the product of both risk and reward. That is to say, in measuring encouragement, the level of any award must be discounted by the likelihood of securing it. ${ }^{64}$ The more certain and potentially greater the recovery, the more likely an attorney is to devote his efforts to the lawsuit. Conversely, holding the amount of the potential fee award constant, a low probability of success will make an attorney less likely to accept a case.

This relationship has led many judges to award multiple fees or contingency

60. See New York Ass'n for Retarded Children, Inc. v. Carey, 711 F.2d at 1151 (2d Cir. 1983) (discussed supra p. 255).

61. See Rowe, supra note 10 , at 661 .

62. See Civil Rights Attorneys' Fees Award Act, 42 U.S.C $\S 1988$ (1980); Equal Access to Justice Act, 28 U.S.C. $\S 2412$ (b) (1982).

63. See Note, Uniform Securities Act: Award and Determination of Attorneys' Fees, 35 S.C.L. Rev. 23, 26 (1983) ("While the . . . provisions allowing successful plaintiffs to recover costs and fees have a punitive effect, the defendant's punishment should not be determined by the opposing counsel's hourly market rate.")

64. See Berger, Court Awarded Attomeys' Fees: What is "Reasonable?", 126 U. PA. L. REV. 281, 324-25 (1977). 
bonuses when a particularly complex or novel case is won. 65 The intent is to encourage such litigation by increasing the reward to compensate for the risk. ${ }^{66}$ There are two problems with this approach, however. First, a discretionary bonus, coming upon successful completion of the case, cannot serve as an encouragement to take a case. Rather, it is an encouragement to do a good job once a case has already been accepted. The decision to accept a case more likely depends on the attorney's assessment of its merits, his interest in it, and the state of his calendar. Furthermore, once an attorney takes on the case, he is bound by professional ethics to provide competent and diligent representation. ${ }^{67}$ If extraordinary efforts are expended and unexpected successes are achieved as a result, then a bonus for exceptional service may be in order. ${ }^{68}$ However, as such rewards do not compensate for the original riskiness of the case, they cannot function as encouragement to take cases.

The second problem with encouragement bonuses is that the higher the rate is, the more likely fee shifting will not simply replicate the rate which would prevent attorneys from turning down meritorious cases because of economic need, but rather will skew the legal market in favor of bringing certain categories of lawsuits, regardless of their merits. Higher-than-market rates wll certainly encourage litigation in a particular area, but the potential reward may be so high as to overcompensate for the riskiness of a suit with little merit. ${ }^{69}$ In addition, such overpayment

65. See Beecher v. Able, 435 F. Supp. 397, 418 (S.D.N.Y. 1977) (fee tripled because of "unusual risk or contingency factor involved"); Leubsdorf, The Contingency Factor in Attomey Fee Awards, 90 YALE L.J. 473, 473 n.1 (1981). But of. Blum v. Stenson, 104 S. Ct. 1541, 1548 (1984) (district court award of 50\% bonus reversed: "The novelty and complexity of the issues presumably were fully reflected in the number of billable hours recorded by counsel. ..").

66. The corollary that simple or certain litigation should earn a lower fee may or may not follow. Compare Rowe, supra note 10, at 669 ("[W]hen a civil rights plaintiff has a strong substantial damage claim that makes no significant contribution to precedent, he needs little or no extra encouragement to bring his claim and may not qualify for a fee award.'), with Hughes v. Repko, 578 F.2d 483, 487 (3d Cir. 1978) (district court cannot reduce fee award to successful plaintiffs because of the simplicity of the case).

67. See American Bar Ass'n, Model Rules of Professional Conduct, Rules 1.1, 1.3 (1983); Model Code of Professional Responsibility Canon 7 (1979).

68. See Blum, 104 S. Ct. at 1550.

69. Economic analysis elucidates how fee shifting affects the frequency of litigation. There are three principal articles applying economic analysis to fee shifting issues: Posner, An Economic Approach to Legal Procedure and Judicial Administration, 2 J. LEGal STUD. 399 (1973); Shavell, Suit, Settlement, and Trial: A Theoretical Analysis Under Alternative Methods for the Allocation of Legal Costs, 11 J. LEGAL STUD. 55 (1982); Priest, Regulating the Content and Volume of Litigation: An Economic Analysis, 1 SUP. CT. ECON. Rev. 163 (1982). The approach of these articles derives from Landes, An Economic Analysis of the Courts, 14 J. LAW \& ECON. 61 (1971).

Present fee award statutes are generally considered to incorporate what economists call a "favored plaintiffs" rule because they are typically applied in the case of successful plaintiffs. Such a rule will affect both the comparative position of plaintiffs and defendants and the frequency of litigation. As its name suggests, the favored plaintiffs rule enhances the position of the plaintiff at the expense of the defendant. Priest, supra. Under such a rule, plaintiffs will be encouraged to sue whenever they believe their suit is meritorious.

However, there is no reason to assume only meritorious actions will be encouraged. Incentives provided by statutory fee awards which operate only in favor of plaintiffs will likely enhance the attractiveness of suits which are less meritorious. When plaintiffs lose, they are not charged for the costs incurred in defending against their invalid claims. Particularly where public interest attorneys provide free representation, such a rule has an indiscriminately encouraging effect on plaintiffs. Furthermore, the shifting of attorney fees will increase the frequency of litigation. This is because the higher the expected value of a suit, determined by the combination of the probability of success and the amount at stake in the case, the 
to attorneys when they prevail effectively subsidizes lawsuits on which they do not prevail. This is contrary to the intent of Congress which has specified that only "prevailing parties are to recover fees."70

Others who are concerned that potential plaintiffs may be dissuaded from litigating have utilized liberal "market rates" in awarding fees. ${ }^{11}$ These judges perhaps seek to encourage litigation by compensating attorneys for their "opportunity cost." A problem arises here, however, when these judges mistake an attorney's public billing rate for his opportunity cost. The mere fact that an attorney has a schedule of billing rates does not mean that he receives those rates at all times and from all clients. He may actually charge each client what the underlying market can bear, using his public rates as a negotiating tool. ${ }^{72}$

Furthermore, even when attorneys establish their public billing rates, courts have been known to reject such clear market evidence in order to award higher fees. For example, Laffey $v$. Northwest Airlines ${ }^{73}$ was a class action Title VII suit brought by female flight attendants. The plaintiffs were represented by a law firm whose clientele consisted primarily of labor unions. The firm regularly charged its clients $\$ 60-100$ per hour. While aware of the firm's actual fee structure, the court awarded them $\$ 75-175$ per hour. These fees were "higher than any hourly rate at which [the firm's] counsel ha[d] ever billed its regular fee-paying clients." 74 The court deemed the law firm's actual rates to be "discounted" in an effort to accomodate their non-profit clients.

The court argued that $\$ 60-100$ per hour did not reflect the "true value of the services rendered" because other firms doing similar anti-discrimination work commanded higher rates. The court assumed that the $\$ 75-175$ range constituted the "prevailing market rate" for Title VII attorneys because some of the larger corporate law firms which took such cases commanded these fees. The court further assumed that the market is the same whether the case is taken by labor union law firms, public interest attorneys, or large corporate firms.

The Laffey court seems to have misunderstood the concept of opportunity cost. In order to compensate accurately for opportunity costs, a court would have to determine what a willing buyer would pay a willing seller for the services rendered. This is a far more complex endeavor than simply multiplying the number

more likely the favored plaintiffs' rule will increase rather than decrease the frequency of litigation because it increases the amount at stake between the parties. Id. at 166.

70. See supra note 25, and Rose, Jones \& Kelly, Reform of Civil Rights Fee Award Practices Needed, in Legal Times 13 (February 13, 1984). The authors also point out that bonuses may have the effect of penalizing the least blameworthy defendants since complex and novel cases, where bonuses are most common, often present very close questions. This point is not lost on courts which follow the English Rule. For example, in Canada, where losing parties typically pay the winner's attorney fees, an exception is made when a new point of law is at issue in the case. In that situation, fees are often not shifted. See P. Lantz, Costs as a Regulatory Device, 2 Advocates' Q. 396, 417 (1981).

71. See Berger, supra note 64 , at $322-23$ and $n .164$.

72. See How Firms Bill, Nat'l L.J., Feb. 27, 1984, at 25.36 for discussion of a variety of billing practices including volume discounts, contingency fees for defense representation, flat fees, and "multiple" rates, which vary according to the identity of the client.

73. 572 F.2d 331 (D.C. Cir. 1983). See also Brief for the United States as Amicus Curiae at 6, Laffey v. Northwest Airlines, 572 F.2d 331 (D.C. Cir. 1983).

74. Laffey, 572 F.2d at 372 . 
of hours worked times a supposed "prevailing market rate." As Judge Wilkey has observed, where profit-making corporate law firms take on a Title VII civil rights case pro bono,

[ $\mathrm{t}]$ here is missing an a priori pecuniary relation between the legal services undertaken and the willingness of any beneficiary to pay for them. Therefore, charging a losing defendant for the prevailing party's legal expenses at "market" rates which no one would ever have voluntarily assumed is to destroy the market concept by purporting to respect it. ${ }^{75}$

As noted above, Copeland III had rejected the cost-plus approach of Copeland I and Copeland $I I$ in part on the grounds of administrative difficulty. However, the need to determine a true market rate for different types of litigation in different locales is equally, if not more, difficult. First, deliniting the relevant market is a complex matter. This results from having to fix relevant market factors and to quantify them for purposes of analysis. The major area of the law in which a definition of market has been attempted is the field of antitrust. To define a market under current antitrust analysis, "one must decide the geographic dimension, the product dimension (what products are close enough substitutes to be included in the same market), and the production dimension (what products are or can be manufactured with the same production facilities)."76 These factors suggest a number of analogous inquiries which may be posed.

As to the "geographic" dimension, one might be tempted to view the provision of legal services as part of a national market. Certainly the billing rates in New York differ markedly from those in Indianapolis. Examination of the "product" dimension also suggests a host of questions. Are the attributes of civil rights litigation and corporate litigation sufficiently similar to justify equivalent market rates? Would a corporate client view an experienced civil rights attorney as a substitute for counsel in corporate litigation? With regard to the production dimension, does the fact that corporate and civil rights legal services can be provided by the same attorney indicate a single market? Or should they be treated as potential entrants

75. Copeland III, 641 F.2d at 914 (Wilkey, J., dissenting).

76. P. Areeda \& D. Turner, Antitrust LaW |f 517 (1978).

An examination of the "product" dimension in turn calls for "an appraisal of the "cross-elasticity" of demand" to determine whether "commodities [are] reasonably interchangeable by consumers for the same purposes." United States v. E.I. duPont de Nemours \& Co., 351 U.S. 377, 394-95 (1956). Reasonable interchangeability involves three components: price, use, and quality. These factors, as applied, focus on the consumer's perceptions.

In applying the quality test to the legal market, the question posed would be whether the attributes of welfare litigation and corporate litigation are sufficiently similar. Id. at 397. Certainly, both may be complex. But even if the inquiry as to similar attributes were to end there, there is only one factor favoring a finding that welfare law and corporate law are one market. Application of the second and third components points to considering the two areas of practice as two distinct markets.

The use test is a question of functional interchangeability. Id. at 399. In this regard, it is doubtful whether many corporate clients would be comfortable substituting a welfare attorney as counsel in corporate litigation. Under the price test, "[i]f a slight decrease in the price of [one product] causes a considerable number of customers of [another] to switch . . ., it would be an indication that a high cross-elasticity of demand exists between them ...." Id. at 400. It is again doubtful whether any reduction in fees charged by a welfare attorney could cause corporate clients to hand over their business.

This thumbnail sketch only demonstrates the lack of refined analysis by courts which subscribe to a uniform market rate. Although a comparison of the market compensation formula for public interest litigation with the market inquiry posed by antitrust law can be faulted as comparing apples and oranges, it is, nonetheless, useful in emphasizing the limits of a simplistic analysis - that welfare law and corporate law are a single market simply because both involve the practice of complex law. 
to the same market? Would the necessary adjustment on the part of the attorney be minor or major? What additional elements of time, cost, and education would be required in a change in the type of practice? That these questions have not been addressed, much less answered, demonstrates the lack of serious market analysis by courts that subscribe to a uniform market rate.

Second, once a market is delineated it is no simple matter to determine the rate which supposedly "prevails" in that market. This issue, with which courts regularly grapple, has numerous facets. A basic problem is that the public possesses little accurate information concerning fees charged by law firms. In some instances, such as bankruptcy fees, fee awards approved or ordered by a court necessarily become part of the public record. But more generally, the factual data regarding fees have remained the proprietary information of law firms, which guard this information closely. ${ }^{77}$

Thus, courts typically rely on approximations of the market rate in ordering fee awards. In most instances, attorneys submit affidavits as to fees they charge in cases of analogous complexity. ${ }^{78}$ For example, an NAACP Legal Defense Fund attorney might proffer an affidavit to the court describing fee awards he received in Title VII cases. Such an affidavit would then be used as evidence of the "market rate" for that attorney. The danger here is that affidavits may become boilerplate, the court accepting statements about prior fees without a rigorous review process. There is nothing to guarantee that earlier awards were based on satisfactory analysis. Although some courts have determined that evidentiary hearings are not required where there is no controversy over fee claims which are fully substantiated, ${ }^{79}$ evidentiary hearings to review affidavits are often held. ${ }^{80}$ Where required, such hearings constitute an additional complexity in the determination of market-based fees. Furthermore, attorneys rarely admit to discounting of fees or partial fee collection. Rather, in such circumstances one tends to claim one's top fee whether or not one receives it all the time.

Courts must also deal with the problem of overcompensated time. Not only have courts recognized the need to reduce hourly rates for such non-attorney personnel as secretaries, paralegals, and law students, ${ }^{81}$ they also must distinguish

77. Indeed, one of the frequent complaints about Copeland $I$ was that the cost-plus-profit approach would lead to an opening of the books of major Washington law firms. Royce Lamberth, an Assistant U.S. Attorney in the District of Columbia, has attempted to secure, by subpoena, the files of the D.C. Bar's Lawyer Referral and Information Service List where many lawyers who handle employment discrimina. tion suits have listed their fees. Lamberth contends that this information will provide "true" fees charged in Title VII cases. Washington Post, Jan. 17, 1983, at D2, col. 1. The D.C. Bar has resisted this effort. In a recent Title VII case, Laffey v. Northwest Airlines, 572 F. Supp. 354 (D.D.C. 1983), Chief Judge Robinson opened the record on affidavits submitted by D.C. law firms to support plaintiff attorneys' claim as to the market rate for Title VII cases. See What a D.C. Hour is Worth: Who Charges What?, Nat'l L.J., Aug. 15, 1983, at 2 , col.4.

78. See Berger, supra note 64 , at $321 \& \mathrm{n} .161$.

79. See King v. McCord, 621 F.2d 205, 206 (5th Cir. 1980); In re First Colonia Corp. of Am., 544 F.2d 1291, 1300 (5th Cir.), cett. denied, 431 U.S. 904 (1977); Imprisoned Citizens Union v. Shapp, 473 F. Supp. 1017, 1021 (E.D. Pa. 1979).

80. See Manhart v. City of Los Angeles, 652 F.2d 904, 908 (9th Cir. 1981); Lipscomb v. Wise, 643 F.2d 319, 323 (5th Cir. 1981); Williams v. Alioto, 625 F.2d 845, 849 (9th Cir. 1980) (per curiam); Farris v. Cox, 508 F. Supp. 222, 227 n.16 (N.D. Cal. 1981).

81. See, e.g., City of Detroit v. Grinnell Corp., 495 F.2d 448, 473 (2d Cir. 1974); Ross v. Saltmarsh, 521 
between attorney hours billed for legal work and attorney hours billed for work that could (and would) otherwise have been done by a paralegal or research assistant. ${ }^{82}$

Another difficult situation arises where a law professor is a public interest litigator on the side. A professor can neither provide an hourly salary figure, since his only commitment is to teach a certain number of courses, nor compute overhead costs, because his office and support staff are provided by the university. Ostensibly, then, the value of a law professor's marginal time is whatever amount others are prepared to pay for it. This inherent lack of precision makes it difficult for courts to evaluate professorial fee requests. ${ }^{83}$

In reaction to the many complexities faced in determining precise market rates, ${ }^{84}$ suggestions have been made for approximating fees in a different manner. In situations where the government is the defendant, for example, it has been proposed that courts award plaintiffs' attorneys the same amount the government

F. Supp. 753, 762-64 (S.D.N.Y. 1981); Kane v. Martin Paint Stores, Inc., 439 F. Supp. 1054, 1055-56 (S.D.N.Y. 1977), affd, 578 F.2d 1368 (2d Cir. 1978). In some cases courts have distinguished between incourt and out-of-court time. See, e.g., Corpus v. Estelle, 605 F.2d 175, 180 n.10 (5th Cir. 1979), cert. denied, 445 U.S. 919 (1980); Miller v. Carson, 563 F.2d 741, 756 (5th Cir. 1977); Dunten v. Kilber, 518 F. Supp. 1146, 1152 \& n.4 (N.D. Ga. 1981); Langdon v. Drew Mun. Separate School Dist., 512 F. Supp. 1131,1139 (N.D. Miss. 1981).

82. See Johnson v. Georgia Highway Express, Inc., 488 F.2d 714, 717 (5th Cir. 1974); Dunsten v. Kibler, 518 F.Supp. 1146, 1152 \& n.4 (N.D. Ga. 1981); Cf. Blank v. Talley Indus., Inc., 390 F. Supp. 1, 4 (S.D.N.Y. 1975) (improper to charge partner's hourly rate for work capable of performance by junior associate).

83. For example, Harvard law professor Lawrence Tribe has recently requested over $\$ 400$ per hour for his successful challenge to a Massachusetts law entitling schools and churches to veto city liquor license grants to nearby establishments. See Massachusetts Battles Lawyers over \$332,441 Rights Fee Case, N.Y. Times, Dec. 14, 1983, at A22. Tribe is renowned for his expertise in constitutional law and is in great demand as a litigator in particularly difficult cases. Nonetheless, when one's income need not be shared with a partnership nor applied to overhead, it is difficult to comprehend the logic of charging hourly fees "commensurate" with those of a large law firm.

84. Courts also face difficulties in determining fees awardable to pro se litigants. The "market" cannot really help here. Rather, the question of how to treat pro se litigants for fee award purposes is an issue the resolution of which depends on one's view of the purposes of statutory fee awards. Courts have divided on this issued both for pro se litigants in general, compare Turman v. Tuttle, 711 F.2d 148 (19th Cir. 1983) (pro se layman in $\S 1983$ suit denied attorney fee award) and Barratt v. Bureau of Customs, 651 F.2d 1087 (5th Cir. 1981) (pro se layman denied fee award in Privacy Act suit) with Cox v. Department of Justice, 601 F.2d 1 (D.C. Cir. 1979) (pro se layman in FOIA suit may be entitled to fee award), and for attorneys proceeding pro se. Compare Cazalas v. Department of Justice, 709 F.2d 1051 (7th Cir. 1983) (fee award to pro se attorney in FOIA and Privacy Act suit) and Cuneo v. Rumsfeld, 553 F.2d 1360 (D.C. Cir. 1977) (fee award to pro se attorney in FOIA suit) with Falcone v. Internal Revenue Serv., 714 F.2d 646 (6th Cir. 1983) (fee award denied pro se attorney in FOIA suit) and White v. Arlen Realty \& Dev. Corp., 614 F.2d 387 (4th Cir. 1980) (fee award denied pro se attorney in Truth in Lending Act suit).

Non-attorney pro se litigants do not incur typical attorney expenses in bringing lawsuits, so any decision to allow them a fee equivalent must be based on either the encouragement or the punishment theory. An out-of- pocket rationale could also apply, however, if a fee award were viewed as reimbursement for opportunity costs of the pro se litigant. Such opportunity costs might be difficult to quantify, but at least one court has suggested that a pro se plaintiff who can show that prosecution of his claim diverted him from income-producing activity would be entitled to a fee award. Crocker v. United States Dept. of Treasury, 634 F.2d 48, 49 (2d Cir. 1980).

It has been asserted that opportunity costs can more easily be ascertained for attorneys proceeding pro se, "for the work foregone is of the same nature as that actually performed." Cazalas, 709 F.2d at 1057. This assumption may not be correct in all cases, however. A court cannot merely assume an attorney proceeding pro se turned down willing fee-paying clients in order to devote his efforts to the present case. Inquiry beyond the billing rate is required here, too. 
pays for its legal advice. ${ }^{85}$ Generally, government attorneys handle the defense in suits against the United States. Their cost to the government is a function of their annual salary and average hours worked, plus proportionate overhead. However, when in-house attorneys require special assistance, outside counsel may be retained, and their cost is generally higher. While the Justice Department limits reimbursement to outside counsel to $\$ 75$ per hour, other government agencies pay substantially more, complicating the selection of a single government attorney rate.

One solution would be to provide a range of "going rates" for government attorneys based on years of experience. ${ }^{86}$ Another, which has received considerable attention recently, is to establish a "fee cap" based upon a senior government attorney's salary plus overhead. ${ }^{87}$ The Justice Department's bill on attorney fees, currently pending in Congress, provides maximum compensation of $\$ 75$ per hour to attorneys who successfully sue the government on civil claims. ${ }^{88}$ The figure is "commensurate with-but still significantly higher than" compensation of the government's own senior attorneys and reflects an effort to correlate the fee claims of plaintiffs' attorneys with the cost of litigation to the government. ${ }^{89}$ The argument for a cap is that it approximates a "reasonable" fee figure without requiring analysis of the personal books of attorneys and their law firms. Thus, it provides a "bright line" figure for fee awards. A cap also presumably reflects some congressional judgment-hopefully informed or studied-as to what the monetary value of legal work ought to be in suits against the government. It is a statement as to what a "fair" rate of payment would be, not necessarily a prediction of what the "market" rate might be. ${ }^{90}$ Alternatively, it may simply reflect a disinclination to

85. See Sylvester, OMB's New Assault on Legal Fees, Nat'l. L.J., Nov. 29, 1982, at 1, col. 4.

86. This is the manner in which the Department of Justice determines how much to pay outside counsel. While paralegal services are compensated at the rate of $\$ 30$ per hour, attorneys earn from $\$ 50$ to $\$ 75$ per hour, depending on years of practicing experience. See General Accounting Office Report, Justice Expenditures For Private Counsel and Judicial Fee Awards in Antitrust and Securities Cases, GAO/GGD84-2, October 7, 1983, at 5-6.

87. The idea of a fee cap is not new to Congress. A $\$ 75$ cap is used in fee shifting under the Equal Access to Justice Act, 28 U.S.C. $\S 2412$ (d)(2)(A) (1982). See also Model Rules for Implementation of Equal Access to Justice Act, 46 Fed. Reg. 32,900, 32,904 (1981).

Also, a two-step cap is currently applied in awarding fees under the Criminal Justice Act. 18 U.S.C. $\S 3006 \mathrm{~A}$ (1982 and Supp. V 1983). Under that Act, attorneys appointed to represent indigent defendants receive fees of $\$ 30$ per hour for court time and $\$ 20$ per hour for out-of-court time. The Criminal Justice Act also contains a cap of $\$ 1,000$ for felony cases and $\$ 400$ for misdemeanors, id. $\$ 3006 \mathrm{~A}(\mathrm{~d})(2)$, which can be waived for "extended or complex" representation. Id. $\S 3006 \mathrm{~A}(\mathrm{~d})(3)$. It is an abuse of discretion for a trial court to use the Criminal Justice Act rates as a guide when setting fees under the Civil Rights Attorneys' Fee Award Act. 42 U.S.C. $§ 1988$ (Supp. IV 1981). See Gurule v. Wilson, 635 F.2d 782, 793 (10th Cir. 1980).

88. See The Legal Fees Equity Act, S. 2802, 98th Cong., 2d Sess. (1984). The bill also proposes to double the compensation provided under the Criminal Justice Act to attorneys representing indigent criminal defendants.

89. See 130 ConG. Rec. S8498 (daily ed. June 27, 1984) (statement of Senator Thurmond).

90. Some arguments regarding fair government subsidy have developed in the discussion of fees for a criminal defense attorney under the Criminal Justice Act. 18 U.S.C. § 3006A (1982 and Supp. V 1983). An indication of the problem is the recent strike by Washington, D.C. attorneys operating under the Criminal Justice Act, which underscored the claim that fees to attorneys representing indigents, which have not changed for more than thirteen years, are insufficient to attract competent counsel to criminal defense work. Note, however, that in the criminal defense context the aim is to ensure fair and quality representation for injured defendants and thus to encourage attorneys to take the time necessary to do a good job, not 
spend more government money for legal assistance.

While a fee cap cannot account for true differences in costs incurred by attorneys, it does provide a baseline for fee determinations. It allows the court to set fees without utilizing cost accounting techniques. On the other hand, the "cap" is vulnerable to the criticism that, as a "bright line," it opts for ease of application over accuracy in reimbursement. ${ }^{91}$

The concept of a "break point billing rate" similarly serves as a bright line, but is more flexible than a federally-mandated cap. As advocated in Carey, ${ }^{92}$ each district judge would be expected to familiarize himself with the range of billing rates in the community and to select a break point figure beyond which compensation would be deemed a significant windfall to non-profit attorneys. One could also make use of the break point concept by determining maximum fees for particular types of cases. Rather than inquiring into the specifics of each case and the market relationship of the particular parties, judges would establish maximum rates for particular services performed by attorneys in their communities. Indeed, the market itself has developed a similar approach. Paying clients and their firms generally have in mind a certain amount a case should cost regardless of the hours expended. Bills are adjusted to reflect the reasonable cost of the services rendered if actual hours spent are not in line with these expectations.

\section{$\mathrm{V}$ \\ Reasonable Fees after BLUM $V$. STENSON}

In Blum v. Stenson, the Supreme Court held that "reasonable fees" under the Civil Rights Attorneys' Fees Awards Act meant prevailing market rates. ${ }^{93}$ It also determined that the prevailing rate in any given community would be the same for private and non-profit counsel. ${ }^{94}$ Thus, the Court identified "the market" with "reasonableness."

In a footnote, however, the Court recognized the doubtful wisdom of such a view by noting that the concept of a single market for attorney fees abstracts from reality, and by admitting that constraints which apply to fees in the ordinary attorney-client context are neither present nor compensated for in court ordered fee award determinations. ${ }^{95}$ In support of the first point, the Court made reference to the variety of services rendered by attorneys and to the disparity in rates which results therefrom. Regarding the second point, the Court noted that fees are typically negotiated with clients. Indeed, as the Copeland II court noted, fees are

merely to encourage attorneys to take the case. Even under such circumstances, however, Judge Harold Greene has said, "Taxpayers should not be expected to pay criminal defense attorneys at the same rate that General Motors, AT\&T and Mobil Oil pay for their own representation." Greene, Be Fair to Lawyers-And to Defendants, Washington Post, Sept. 12, 1983, at A13, col. 2. While Greene supports an increase in the District of Columbia Criminal Justice Act subsidy, he recognizes that the equivalent of private-sector fees is not intended.

91. Also, this approach has so far been limited to fee awards in suits against the government. For other cases, the problems in determining "prevailing market rates" remain.

92. Carey, 711 F.2d at 1151 .

93. 104 S. Ct. at 1547 .

94. Id.

95. Id. at 1547 n.11. 
adjusted in these negotiations in accordance with a number of considerations, including the benefit achieved, the client's ability to pay, and the likelihood of future business from the client. ${ }^{96}$ In contrast, as the Blum Court admitted, awards under fee shifting statutes are made by the court "in an entirely different setting" with the fee paid by the losing party. ${ }^{97}$

Although the Supreme Court was aware that the market approach was seriously flawed, it nonetheless deferred to the view of several lower courts and adopted the simplistic position that "prevailing rates" are ipso facto reasonable. We are left with the anomaly of an opinion which mandates calculation of reasonable fees "according to the prevailing market rates in the relevant community" while simultaneously warning that

[m]arket prices of commodities and most services are determined by supply and demand. In this traditional sense there is no such thing as a prevailing market rate for the service of lawyers in a particular community. 98

This contradiction is not resolved in the opinion.

Another example of the failure to consider the limits of a market analysis is the assertion by the Copeland III court that a fee award of $\$ 160,000$ to attorneys who recovered $\$ 33,000$ for their clients compensated them "for the market value of services rendered."99 Clearly none but the wealthiest and most eccentric of clients would contract for "services" in the market at a price five times their value. This is not to deny that reasonable persons may assign value to the vindication of principles or the achievement of favorable precedents; it is simply to point out that the market has no mechanism for assigning dollar values to such desires. ${ }^{100}$ This is particularly so in the fee shifting context: where the clients who do the contracting do not pay the bill, the market cannot provide a reasonable fee.

If the intangible costs of discrimination and pollution and the non-monetary benefits of their abolition could be accounted for by the market, fee shifting statutes would not be necessary to encourage civil rights and environmental litigation. As is the case in personal injury litigation, contingency fees would sufficiently encourage private attorneys to represent wronged plaintiffs. Statutory fee awards were designed precisely to address the inability of the market to produce an optimal level of litigation in these and other categories. Once this is understood, it should become clear that the effort to label as "reasonable" whatever the market is supposed to yield is fundamentally misguided (even if the market analysis used was not fundamentally flawed).

What, then, is required? Congress has mandated "reasonable fees" determined in accordance with the standards laid out in Johnson. Those who say reasonable fees are whatever fees prevail in the market are positivists. Reasonableness requires more. First, it requires a more accurate determination of the various markets in which different legal services are priced. Second, it requires the imposition

96. Copeland II, 20 Fair Empl. Prac. Cas. (BNA) at 79

97. 104 S. Ct. at 1547 n.11.

98. Id. (Emphasis added).

99. Copeland III, 641 F.2d at 894. See supra notes $32-37$ and accompanying text.

100. Even if there were such a mechanism, it would clearly not evaluate the worth of these goals by reference to billing rates of opposing counsel. 
of objectively derived guidelines upon fees found to exist in particular markets. While Congress apparently intended the Johnson factors to serve, they clearly do not provide any predictive guidance. ${ }^{101}$

In sum, reasonableness requires fairness. For example, if an experienced corporate counsel represents a plaintiff in a discrimination case, it is reasonable to inquire whether it is fair for her to charge either the plaintiff or the defendant for her expertise in securities litigation. Hiring overqualified counsel at a premium would seem to be unreasonable. Just as duplicative hours and unnecessarily thorough research are shaved off a bill or fee request, so should charges for additional education and experience which are unnecessary to the case. The same applies to premiums paid to obtain counsel with exquisite offices in prime locations. Such adjustments should precede application of the Johnson factors, for they affect the base rate which is appropriate to the particular market.

Next, the Johnson guidelines must be reasonably applied. For example, in determining "the time and labor required," the court should evaluate the reasonableness of the number of hours charged. ${ }^{102}$ This will require an objective rating of the amount of work different legal tasks should require.

In the absence of such fine-tuning, awards will be excessive. Though public interest advocates may claim fee awards are too low to provide incentives to take cases, ${ }^{103}$ others, including this author, ${ }^{104}$ have suggested and continue to suggest that the present fee structure overencourages litigation. The foregoing discussion has attempted to show how and why this is so.

The crying need in this area is for consistency and objectivity. There are ways to achieve this goal. The first is to require clearer statutory guidelines regarding fee awards. This will necessitate Congressional debate over the justifications for statutory fee shifting. ${ }^{105}$ The pending Legal Fees Equity Act provides the setting for such a debate, ${ }^{106}$ granting an opportunity to plumb the role of litigation and litigators in our social fabric.

Where the government is not a party and, therefore, the Legal Fees Equity Act will not apply, there is no reason why the Judicial Conference cannot recommend detailed guidelines for judges to follow. ${ }^{107}$ Nor is there any reason why these guidelines should not suggest specific monetary figures. In other contexts, market

101. Judge Wilkey, writing of these factors, has said "[t]he imprecision, duplication and contradiction of these factors is obvious." Copeland II, 20 Fair Empl. Prac. Cas. (BNA) at 80 n.2 (D.C. Cir. 1979).

102. Determination of the number of hours reasonably billable may depend on judicial views about the extent to which one has prevailed. See Hensley v. Eckerhart, 103 S. Ct. 1933 (1983).

103. See Steel, Why Attomeys Won't Take Civil Rights Cases, 236 Nation 362 (Mar. 26, 1983).

104. See Breger, Reducing Lawyers' Fees, N.Y. Times, May 27, 1983, at A23.

105. Cf. Blum, $104 \mathrm{~S}$. Ct. at 1547 ("the policy arguments advanced in favor of a cost-based standard should be addressed to Congress rather than to this Court").

106. See supra note 88 and accompanying text.

107. The Judicial Conference is required to conduct a comprehensive survey of the condition of business of United States courts and to submit recommendations to the various courts "to promote uniformity of management procedures and the expeditious conduct of court business." 28 U.S.C. $\$ 331$ (1982).

Furthermore, the conference is required to recommend to the Supreme Court such changes and additions to the rules of practice and procedure as may be desirable "to promote simplicity in procedure, fairness in administration, the just determination of litigation and the elimination of unjustifiable expense and delay ...." Id. 
prices or wages are determined by administrative agencies through extensive data collection and analysis. For example, the Labor Department sets "prevailing wage" rates under the Davis-Bacon Act ${ }^{108}$ by means of an elaborate system which identifies actual contract prices in metropolitan and rural areas throughout the country. ${ }^{109}$ The data is examined and compared against Bureau of Labor Statistics data. Although courts cannot undertake this type of administrative task to determine prevailing attorney fees, other independent bodies certainly could do so. The Judicial conference might set up a project to collect available data and to perform detailed analysis aimed at measuring prevailing market rates for particular types of cases in regions throughout the country.

Another approach which would move toward consistency in fee awards would be to remove the process from the federal judges and assign all fee petitions to a magistrate. That magistrate would quickly build up expertise about fee claims in a community. A common law of fees would then develop and attorneys would be able to determine in advance which claims they could successfully make and how much is likely to be awarded. This resulting consistency would make it easier for them to decide whether or not to take a case. Further, this heavy dose of fee petitions would ensure that the magistrate, in effect a "taxing master" of the English variety, will know better than anyone else the real market for legal services in a community and could make awards accordingly. ${ }^{110}$

These procedural tools for implementing fee shifting by court award will operate differently depending on the theoretical justification for fee shifting which is deemed legitimate by Congress and the courts. These theoretical approaches ought to be exposed and their ramifications fully discussed. Only by understanding the implications of the system they have wrought can Congress and the courts hope to improve upon it.

108. 40 U.S.C. $\S 276(2)(a)(1981)$ (wages paid to laborers and mechanics on public works projects to be based on "prevailing wages" as determined by Secretary of Labor).

109. 29 C.F.R. $\S \S 1.2,1.3$ (1983).

110. See supra note 12 and accompanying text. On taxing masters generally, see Silberman, Masters and Magistrates, Part I: The English Model, 50 N.Y.U. L. REv. 1070 (1975); Silberman, Masters and Magistrates, Part II: The American Analogue, 50 N.Y.U. L. Rev. 1297 (1975). 